\title{
ANALISIS PEMILIHAN MODEL KONTRAK KONSTRUKSI PEKERJAAN PEMBANGUNAN PEMBANGKIT LISTRIK (FIDIC RAINBOW CONTRACT 2017)
}

\author{
oleh : \\ Sevren Buana Putra \\ Teknik Sipil Universitas Mercu Buana \\ Email : sevren.bp47@gmail.com \\ Sarwono Hardjomuljadi \\ Teknik Sipil Universitas Mercu Buana \\ Email : sarwonohm2@gmail.com
}

\begin{abstract}
Abstrak : Dalam melaksanakan pekerjaan pembangkit diharuskan ada suatu kontrak konstruksi yang dapat menghargai semangat keadilan atau keseimbangan antara hak dan kewajiban serta mudah diinterpretasikan oleh para pihak. Makalah ini terdiri dari perbandingan In-House Form of General Conditions of Contract in Indonesia terhadap Model Kontrak FIDIC conditions of contract for EPC/Turnkey. Selain itu bertujuan untuk menganalisis penyebab utama klaim yang sering terjadi pada proyek konstruksi pembangkit listrik di Indonesia. Kemudian mencocokkan penyebab klaim pada In-House Form of General Conditions of Contract, yang kemudian dibandingkan dengan FIDIC conditions of contract for EPC/Turnkey. Metodologi yang digunakan untuk menentukan penyebab klaim tertinggi adalah Relative Important Index (RII), kemudian untuk analisis perbandingannya digunakan Metodologi Comparative. Berdasarkan hasil analisis faktor, ditemukan sepuluh faktor dominan yang menyebabkan klaim di pekerjaan pembangkit, dengan tiga tertinggi : 1) Variation Order, 2) Defective Works, 3) Changes in Scope of Work. Hasil analisis menunjukkan bahwa FIDIC conditions of contract for EPC/Turnkey adalah kontrak yang paling efisien, adil, dan seimbang terhadap manajemen klaim. Berdasarkan hasil penelitian, disarankan untuk mengadopsi model kontrak FIDIC karena memiliki keuntungan pada sebagian besar aspek sebagai model kontrak konstruksi Indonesia.
\end{abstract}

Kata Kunci : Kontrak Konstruksi, FIDIC Conditions of Contract for EPC/Turnkey, RII, Analisis Perbandingan, Model Kontrak

\begin{abstract}
In carrying out the power plant work, a construction contract is required that can respect the spirit of justice or balance between rights and obligations and is easily interpreted by the parties. This paper consists of a comparison of In-House Forms of General Conditions of Contract in Indonesia with the FIDIC conditions of contract for EPC/Turnkey Contract Model. In addition, it aims to analyze the main causes of claims that often occur in power plant construction projects in Indonesia. Then match the cause of the claim in the In-House Form of General Conditions of Contract, which is then compared with the FIDIC conditions of contract for EPC/Turnkey. The methodology used to determine the highest cause of the claim is the Relative Important Index (RII). Then for comparative analysis Comparative Methodology is used. Based on the results of the factor analysis, ten dominant factors were found to cause claims in Power Works, with the highest three: 1) Variation Order, 2) Defective Works, 3) Changes in Scope of Work. The analysis shows that FIDIC conditions of contract for EPC/Turnkey is the most efficient, fair and balanced contract for claim management. Based on the results of the study, it is recommended to adopt the FIDIC contract model because it has advantages in most aspects as an Indonesian construction contract model.
\end{abstract}

Keywords: Construction Contracts, FIDIC Conditions of Contract for EPC/Turnkey, RII, Comparison Analysis, Contract Model 


\section{Pendahuluan}

Sejak dicanangkan pada tahun 2015 oleh Pemerintah Indonesia, program 35.000 megawatt merupakan suatu jawaban dari pertumbuhan konsumsi listrik Indonesia dari tahun ke tahun dimana imbas dari program 35.000 MW tersebut pegembangan kapasitas pembangkit tenaga listrik harus dapat memenuhi pertumbuhan beban dan untuk memenuhi kekurangan pasokan listrik. Pengembangan tenaga listrik juga bertujuan untuk meningkatkan keandalan pasokan, dengan pemanfaatan sumber energi setempat, terutama energi terbarukan.

Berdasarkan temuan pemeriksaan Badan Pemeriksa Keuangan (BPK) Republik Indonesia Semester II Tahun 2016 pada proyek $10.000 \mathrm{MW}$, maka temuan yang melatarbelakangi penelitian ini adalah pada temuan pelaksanaan jenis kontrak turnkey pada pembangunan fast track program pembangkit listrik tenaga uap 10.000 MW tidak sesuai dengan prinsip kontrak turnkey dan terdapat biaya tambahan yang membebani PLN sebesar Rp. 514,15 miliar dan USD 15,91 juta serta berpotensi sengketa Atas pengajuan klaim dari kontraktor sebesar Rp. 449,26 miliar dan USD 24,46 juta. Fokus penelitian ini adalah masalah pelaksanaan jenis kontrak EPC pada pembangun fast track program I (FTP I) pembangkit listrik tenaga uap (PLTU) 10.000 MW tidak sesuai dengan prinsip kontrak EPC/turnkey.

Karena kontrak konstruksi yang tidak sesuai dengan prinsip EPC/turnkey yang dilakukan oleh penyedia jasa menyebabkan banyak permasalahan terjadi. Dengan berlarutlarutnya pelaksanaan proyek tersebut diatas, maka seharusnya ada hal-hal yang dapat diakomodir pada kontrak konstruksi yang membuat pengguna jasa dan penyedia jasa tidak mengalami kerugian yang lebih besar lagi.

Penelitian ini menganalisis suatu model kotrak konstruksi pembangunan pembangkit dengan mencari klausul kontrak konstruksi yang ada pada pekerjaan konstruksi pembangkit dan membandingkan nya dengan Standar Kontrak FIDIC conditions of contract for EPC/turnkey yang dapat digunakan sebagai rekomendasi pada rencana pembangunan pembangkit.

\section{Kontrak Konstruksi}

kontrak konstruksi tidak dapat ditangani dengan pemahaman yang sama dengan kontrak-kontrak lainnya, karena kontrak kosntruksi adalah suatu kontrak yang bersifat dinamis, menjanjikan suatu barang yang belum ada dan masih memerlukan suatu proses menjadi bentuk yang dijanjikan, sehingga harga kontrak akan selalu berubah dari waktu ke waktu, karena adanya perubahan metode pelaksanaan, baik yang diperintahkan oleh pengguna jasa melalui perintah perubahan maupun yang tidak diperintahkan tetapi harus dikerjakan untuk penyelesaian proyek.

Perbedaan lain dengan kontrak pengadaan barang lainnya, adalah karena kontrak konstruksi menjanjikan sesuatu yang belum ada, yang harus diselesaikan oleh kontraktor dengan imbalan pembayaran untuk setiap pekerjaan yang dilakukan kontraktor sejauh kualitas dan kuantitasnya sesuai dengan spesifikasi yang disepakati dalam kontrak (Hardjomuljadi, 2014).

\section{Proyek EPC}

Definisi EPC berdasarkan Construction Industry Institute (CII) adalah suatu arrangement kontrak di mana Owner menyewa sebuah perusahaan engineering 
atau kontraktor untuk mendesain dan membangun secara lengkap suatu fasilitas. Proyek EPC adalah suatu proyek dimana kontraktor mengerjakan proyek dengan ruang lingkup tanggung jawab penyelesaian pekerjaan meliputi studi desain, pengadaan material dan konstruksi serta perencanaan dari ketiga aktivitas tersebut. Iman Soeharto (2001) menyatakan proyek EPC adalah proyek yang cukup kompleks, rumit, serta kaya akan persoalan dan permasalahan.

\section{Standar Kontrak FIDIC Silver Book}

Federation Internationale Des IngenieursConseils atau disingkat dengan istilah FIDIC yang berkedudukan di Geneva, Switzerland didirikan pada tahun 1913 oleh negaranegara Perancis, Belgia dan Swiss. FIDIC menjalani masa yang sulit sampai akhir 1940an dengan jumlah anggota yang berubah, dan semua anggota yang berbasis di Eropa. Namun setelah Perang Dunia ke II, negara Inggris bergabung pada tahun 1949 disusul Amerika Serikat pada tahun 1958. Pada tahun 1959 mereka bergabung dengan Australia, Kanada, dan Afrika Selatan. Asosiasi anggota pertama dari negara berkembang / Newly Industrialized Countries (NIC) bergabung pada tahun 1965 (Afrika Tengah, sekarang Malawi, Zambia dan Zimbabwe) dan pada tahun 1967 (Kolombia) sehingga menjadikan FIDIC menjadi organisasi yang berstandar internasional.

Kemudian edisi pertama dari Rainbow Series dengan perubahan judul menjadi FIDIC Conditions of Contract For Construction yang hingga saat ini masih digunakan secara luas di seluruh dunia dan dikenal sebagai red book / pink book, di samping itu bahkan bekerjasama dengan Multilateral Development Bank, telah diterbitkan FIDIC Conditions of Contract For Construction MDB
Harmonised Edition 2006 dan kemudian 2010.

FIDIC (2010) condition of contract for EPC/turnkey project (silver book) ini merupakan kondisi kontrak yang digunakan pada proyek engineering, procurement dan construction (EPC) dimana kontraktor mengambil sepenuhnya tanggung jawab untuk desain dan pelaksanaan sebuah proyek. Risiko mengenai penyelesaian proyek meliputi biaya, waktu dan kualitas diserahkan kepada kontraktor, tetapi risiko seperti force majeure dan perang menjadi tanggung jawab pengguna jasa.

Dalam FIDIC silver book terdapat 29 subklausul yang sebagian besar membicarakan masalah definisi, peraturan, hukum dan arbitrase, kemudian aspek keuangan terdapat 23 sub-klausul yang sebagian besar mengatur masalah cara pembayaran, selanjutnya aspek waktu terdapat 21 subklausul yang banyak membicarakan sub aspek jadwal pelaksanaan dan masa pemeliharaan, lalu aspek resiko terdapat 10 sub-klausul yang mengatur masalah resiko, tanggung jawab dan asuransi.

\section{Metodologi Penelitian}

Penelitian ini adalah yang pertama kali dilakukan mengenai analisis perbandingan model kontrak pembangkit (In-House Form of General Conditions of Contract) Terhadap model kontrak FIDIC dengan focus pada konstruksi pembangkit. Metode penelitian menggunakan metode kualitatif dan kuantitatif, yang membandingkan penyebab klaim tertinggi dengan klausula-klausula terkait dalam model kontrak pembangkit di 35ndonesia (In-House Form of General Conditions of Contract) terhadap FIDIC Condition of Contract for EPC/Turnkey Project. 


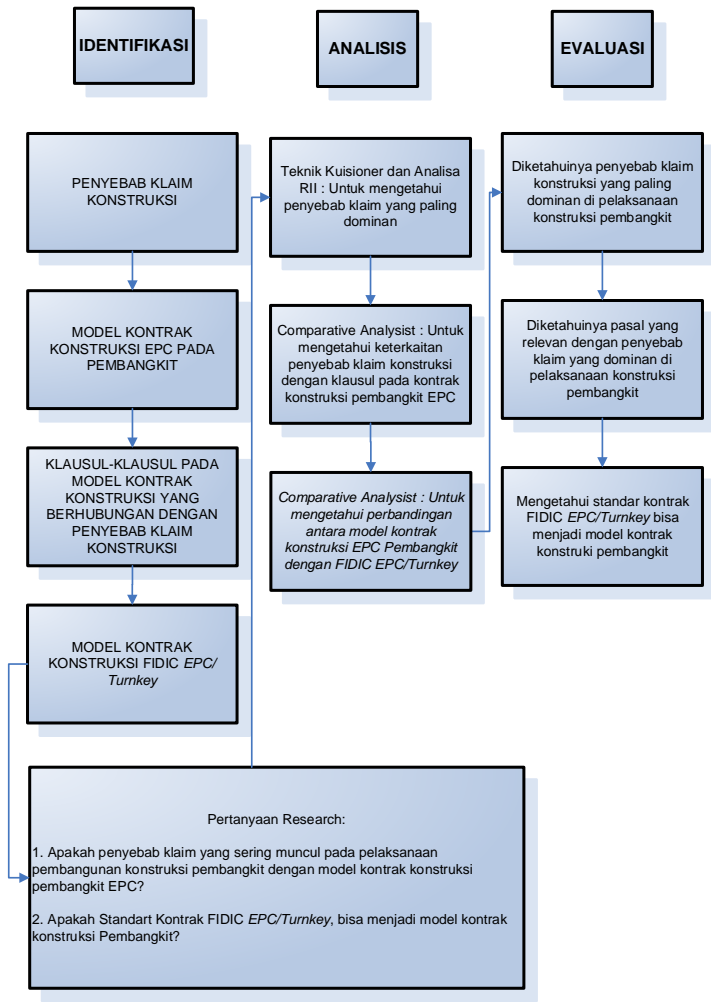

Gambar 1. Kerangka Pemikiran

Dengan demikian maka variabel penelitian merupakan suatu atribut, sifat atau nilai dari subyek, obyek atau suatu kegiatan yang mempunyai variasi tertentu yang telah ditetapkan untuk dianalisis sehingga dapat diketahui hubungan diantaranya dan ditarik kesimpulannya.

Tabel 1. Variabel Penelitian Berdasarkan Survey Pendahuluan

\begin{tabular}{|c|c|c|c|}
\hline No & Variabel & $\begin{array}{l}\text { Penyebab Klaim } \\
\text { (Variabel X) }\end{array}$ & $\begin{array}{c}\text { Klausul Kontrak } \\
\text { EPC FTP I } \\
\text { (In-house form } \\
\text { Contract) } \\
\end{array}$ \\
\hline & & $\begin{array}{l}\text { Pelaksanaan } \\
\text { (Construction) }\end{array}$ & \\
\hline 1 & A1 & $\begin{array}{l}\text { Acceleration and } \\
\text { expenditing }\end{array}$ & $\begin{array}{l}\text { 2.42 Time for } \\
\text { Completion } \\
\text { 2.43 Extension of } \\
\text { Time for } \\
\text { Completion } \\
\text { 2.45 Rates of } \\
\text { Progress } \\
\text { 2.47 Variations } \\
\end{array}$ \\
\hline 2 & A5 & Changes in design & $\begin{array}{l}\text { 2.38 Rejection } \\
2.47 \text { Variations }\end{array}$ \\
\hline 3 & A6 & $\begin{array}{l}\text { Changes in scope of } \\
\text { work }\end{array}$ & $\begin{array}{l}\text { 2.38 Rejection } \\
2.47 \text { Variations }\end{array}$ \\
\hline
\end{tabular}

\begin{tabular}{|c|c|c|c|}
\hline No & Variabel & $\begin{array}{l}\text { Penyebab Klaim } \\
\text { (Variabel X) }\end{array}$ & $\begin{array}{c}\text { Klausul Kontrak } \\
\text { EPC FTP I } \\
\text { (In-house form } \\
\text { Contract) }\end{array}$ \\
\hline 4 & A7 & $\begin{array}{l}\text { Contractor's late } \\
\text { completion }\end{array}$ & $\begin{array}{l}2.38 \text { Rejection } \\
2.40 \\
\text { Commencement of } \\
\text { the Works } \\
2.43 \text { Extension of } \\
\text { Time for } \\
\text { Completion } \\
\text { 2.46 Liquidated } \\
\text { Damages }\end{array}$ \\
\hline 5 & A10 & $\begin{array}{l}\text { Delays caused by the } \\
\text { employer }\end{array}$ & $\begin{array}{l}2.38 \text { Rejection } \\
2.40 \\
\text { Commencement of } \\
\text { the Works } \\
2.50 \text { Termination } \\
\text { for Convenience of } \\
\text { the Owner } \\
2.57 \text { Test on } \\
\text { Completion at Site } \\
\text { 2.56 Owner's } \\
\text { Decision }\end{array}$ \\
\hline 6 & A11 & $\begin{array}{l}\text { Delays caused by the } \\
\text { contractor }\end{array}$ & $\begin{array}{l}\text { 2.38 Rejection } \\
2.40 \\
\text { Commencement of } \\
\text { the Works } \\
\text { 2.43 Extension of } \\
\text { Time for } \\
\text { Completion } \\
\text { 2.46 Liquidated } \\
\text { Damages } \\
\text { 2.53 Delivery } \\
\text { 2.57 Test on } \\
\text { Completion at Site }\end{array}$ \\
\hline 7 & A12 & $\begin{array}{l}\text { Design errors and } \\
\text { omissions }\end{array}$ & $\begin{array}{l}2.59 \text { Defects After } \\
\text { Taking Over }\end{array}$ \\
\hline 8 & A15 & $\begin{array}{l}\text { late drawing and } \\
\text { instruction's approvals }\end{array}$ & $\begin{array}{l}2.40 \\
\text { Commencement of } \\
\text { the Works } \\
2.43 \text { Extension of } \\
\text { Time for } \\
\text { Completion } \\
2.47 \text { Variations } \\
2.43 \text { Extension of } \\
\text { Time for } \\
\text { Completion } \\
\end{array}$ \\
\hline 9 & A18 & $\begin{array}{l}\text { Project planning and } \\
\text { interfacing }\end{array}$ & $\begin{array}{l}2.10 \text { Inspection of } \\
\text { Site } \\
2.35 \text { Inspection and } \\
\text { Tests }\end{array}$ \\
\hline 10 & A19 & $\begin{array}{l}\text { Possesion of site and } \\
\text { availability }\end{array}$ & $\begin{array}{l}\text { 2.10 Inspection of } \\
\text { Site } \\
2.29 \text { Supply of } \\
\text { Plant Materials and } \\
\text { Labour } \\
2.35 \text { Inspection and } \\
\text { Tests } \\
2.41 \text { Allocation of } \\
\text { Site } \\
\text { 2.48 Forfeiture } \\
\text { 2.53 Delivery }\end{array}$ \\
\hline 11 & A21 & $\begin{array}{l}\text { Suspension of the } \\
\text { works }\end{array}$ & $\begin{array}{l}\text { 2.19 Force Majeure } \\
\text { 2.46 Liquidated } \\
\text { Damages } \\
\text { 2.48 Forfeiture } \\
\text { 2.56 Owner's } \\
\text { Decision }\end{array}$ \\
\hline
\end{tabular}




\begin{tabular}{|c|c|c|c|}
\hline No & Variabel & $\begin{array}{l}\text { Penyebab Klaim } \\
\text { (Variabel X) }\end{array}$ & $\begin{array}{c}\text { Klausul Kontrak } \\
\text { EPC FTP I } \\
\text { (In-house form } \\
\text { Contract) }\end{array}$ \\
\hline 12 & A23 & Variation in quantity & $\begin{array}{l}\text { 2.9 Performance } \\
\text { Security } \\
\text { 2.47 Variations } \\
\text { 2.43 Extension of } \\
\text { Time for } \\
\text { Completion } \\
\text { 2.63 Correction and } \\
\text { with Holding of } \\
\text { Certificate }\end{array}$ \\
\hline \multirow[t]{2}{*}{13} & A24 & Work stoppages & $\begin{array}{l}\text { 2.19 Force Majeure } \\
\text { 2.46 Liquidated } \\
\text { Damages } \\
\text { 2.48 Forfeiture }\end{array}$ \\
\hline & & $\begin{array}{l}\text { KEADAAN ALAM } \\
\text { (Physical) }\end{array}$ & \\
\hline 14 & B4 & $\begin{array}{l}\text { Subsurface conditions } \\
\text { of ground water }\end{array}$ & $\begin{array}{l}\text { 2.10 Inspection of } \\
\text { Site } \\
2.35 \text { Inspection and } \\
\text { Tests } \\
\text { 2.41 Allocation of } \\
\text { Site } \\
\text { 2.47 Variations } \\
\end{array}$ \\
\hline \multirow[t]{2}{*}{15} & B5 & $\begin{array}{l}\text { Unforseeable physical } \\
\text { conditions }\end{array}$ & $\begin{array}{l}\text { 2.10 Inspection of } \\
\text { Site } \\
2.35 \text { Inspection and } \\
\text { Tests } \\
2.41 \text { Allocation of } \\
\text { Site } \\
\text { 2.47 Variations } \\
\text { 2.43 Extension of } \\
\text { Time for } \\
\text { Completion }\end{array}$ \\
\hline & & $\begin{array}{l}\text { KINERJA } \\
\text { (Performance) }\end{array}$ & \\
\hline 16 & $\mathrm{C} 2$ & Defective works & $\begin{array}{l}\text { 2.38 Rejection } \\
\text { 2.49 Urgent } \\
\text { Repairs } \\
\text { 2.53 Delivery } \\
\text { 2.58 Taking Over } \\
\text { 2.59 Defects After } \\
\text { Taking Over } \\
\text { 2.63 Correction and } \\
\text { with Holding of } \\
\text { Certificate }\end{array}$ \\
\hline 17 & $\mathrm{C} 10$ & $\begin{array}{l}\text { Slow decision making } \\
\text { involving all parties }\end{array}$ & $\begin{array}{l}\text { 2.56 Owner's } \\
\text { Decision } \\
\text { 2.65 Notices }\end{array}$ \\
\hline \multirow[t]{2}{*}{18} & $\mathrm{C} 11$ & Suitability of materials & $\begin{array}{l}\text { 2.9 Performance } \\
\text { Security } \\
\text { 2.29 Supply of } \\
\text { Plant Materials and } \\
\text { Labour } \\
\text { 2.35 Inspection and } \\
\text { Tests } \\
\text { 2.38 Rejection } \\
\text { 2.43 Extension of } \\
\text { Time for } \\
\text { Completion } \\
\end{array}$ \\
\hline & & $\begin{array}{l}\text { KONTRAKTUAL } \\
\text { (Contractual) }\end{array}$ & \\
\hline 19 & D1 & $\begin{array}{l}\text { Ambiguities in contract } \\
\text { documents }\end{array}$ & 2.1 Definitions \\
\hline 20 & D2 & $\begin{array}{l}\text { Constructive change } \\
\text { orders }\end{array}$ & 2.65 Notices \\
\hline
\end{tabular}

\begin{tabular}{|c|c|c|c|}
\hline No & Variabel & $\begin{array}{l}\text { Penyebab Klaim } \\
\text { (Variabel X) }\end{array}$ & $\begin{array}{c}\text { Klausul Kontrak } \\
\text { EPC FTP I } \\
\text { (In-house form } \\
\text { Contract) }\end{array}$ \\
\hline 21 & D3 & $\begin{array}{l}\text { Delayed dispute } \\
\text { resolution }\end{array}$ & $\begin{array}{l}\text { 2.46 Liquidated } \\
\text { Damages } \\
2.51 \text { Settlement of } \\
\text { Disputes }\end{array}$ \\
\hline 22 & D4 & $\begin{array}{l}\text { Delayed payment on } \\
\text { contract and extras }\end{array}$ & $\begin{array}{l}\text { 2.9 Performance } \\
\text { Security } \\
\text { 2.53 Delivery } \\
\text { 2.58 Taking Over } \\
\text { 2.61 Payment } \\
\text { Certificate } \\
\text { 2.64 Payments due } \\
\text { from the Contractor } \\
\text { 2.68 Effectiveness }\end{array}$ \\
\hline 23 & D5 & $\begin{array}{l}\text { Different interpretation } \\
\text { of contract document }\end{array}$ & $\begin{array}{l}2.53 \text { Delivery } \\
2.65 \text { Notices }\end{array}$ \\
\hline \multirow[t]{2}{*}{24} & D6 & Variation order & $\begin{array}{l}\text { 2.9 Performance } \\
\text { Security } \\
\text { 2.47 Variations } \\
\text { 2.43 Extension of } \\
\text { Time for } \\
\text { Completion } \\
\end{array}$ \\
\hline & & $\begin{array}{l}\text { PIHAK KETIGA } \\
\text { (Third Parties) }\end{array}$ & \\
\hline 25 & E1 & $\begin{array}{l}\text { Changes in law and } \\
\text { regulations }\end{array}$ & $\begin{array}{l}\text { 2.22 Compliance } \\
\text { with Statutes and } \\
\text { Regulations } \\
2.66 \\
\text { Implementation } \\
\text { Procedures } \\
\text { 2.67 Law }\end{array}$ \\
\hline 26 & E6 & Inflation & $\begin{array}{l}\text { 2.9 Performance } \\
\text { Security }\end{array}$ \\
\hline 27 & E7 & Interest rate & $\begin{array}{l}\text { 2.9 Performance } \\
\text { Security }\end{array}$ \\
\hline
\end{tabular}

Metode analisis yang digunakan dalam penelitian ini adalah Relative Importance Index (RII) dan Comparative Analysist. RII adalah suatu analisis yang memungkinkan suatu kuantitatif relative, dimana semakin tinggi peringkat (rating) semakin tinggi pula pengaruh yang diberikan oleh variabel yang dimiliki Sarwono (2009). Sedangkan untuk comparative Janalysis menurut Sugiyono (2014) adalah penelitian yang membandingkan keadaan satu variabel atau lebih pada dua atau lebih sampel yang berbeda, atau dua waktu yang berbeda. Adapun penerapan penelitian komparatif pada penelitian ini digunakan untuk mengetahui perbandingan antara klausul kontrak konstruksi EPC fast track program I (FTP I) dengan klausul kontrak konstruksi FIDIC conditions of contract for EPC/turnkey. 
Persamaan 1. Analisis Data Menggunakan Relative Importance Index (RII)

$$
R I I=\frac{\sum W}{A \cdot N}
$$

Dimana :

$$
\begin{aligned}
\Sigma \mathrm{W}= & \text { bobot masing-masing faktor oleh } \\
& \text { responden } \\
\mathrm{A} & =\text { bobot tertinggi (dalam hal ini } 4) \\
\mathrm{N} & =\text { jumlah responden }
\end{aligned}
$$

\section{Lokasi Penelitian}

Peneltian ini berlokasi di Indonesia dengan melihat model kontrak konstruksi pembangkit (In-House Form of General Conditions of Contract) yang digunakan pada pekerjaan fast track program I (FTP I) tahun 2006.

\section{Populasi dan Sampel Penelitian}

Populasi dari penelitian ini adalah pengguna jasa di bidang hukum, pengadaan dan Engineering yang berpengalaman mengerjakan pembangunan pembangkit dan pengalaman sebagai pengguna kontrak konstruksi. Pengambilan sampel dilakukan kepada pengguna jasa yang memiliki pengetahuan tentang model kontrak, khususnya kontrak EPC fast track program I (FTP I) dengan FIDIC conditions of contract for EPC/turnkey.

\section{Jenis Data}

Sumber data penelitian ini merupakan faktor penting yang menjadi pertimbangan dalam menentukan metode pengumpulan data. Data yang digunakan dalam penelitian ini dapat dibagi menjadi dua, yaitu:

\section{Data primer}

Data primer adalah data yang diperoleh atau dikumpulkan langsung di lapangan oleh orang yang melakukan penelitian atau yang bersangkutan yang memerlukannya ( $M$. Iqbal. 2002). Data primer yang didapatkan adalah model kontrak konhstruksi pembangkit fast track program I (FTP I) dan penyebab klaim konstruksi pada konstruksi pembangkit.

\section{Data sekunder}

Data sekunder yaitu data yang diperoleh dalam bentuk yang sudah jadi berupa publikasi, data tersebut diperoleh melalui studi kepustakaan yaitu dengan membaca kepustakaan seperti buku-buku literatur, diktat-diktat kuliah, majalah-majalah, jurnal-jurnal, buku-buku yang berhubungan dengan pokok penelitian, surat kabar dan membaca arsip-arsip atau dokumendokumen yang terdapat di instansi terkait (M. Iqbal, 2002). Berdasarkan beberapa jurnal pendahulu seperti "Risk Factor Indentification for EPC Contract of Power Plant Projects using In-House From of General Conditions of Contract in Indonesia" (sudirman, 2018) dan Analisis Faktor Penyebab Klaim Pada Proyek Konstruksi Yang Menggunakan FIDIC Conditions of Contract for Plant and Design Build (Taurano, 2013).

\section{Analisis dan Pembahasan}

Analisa RII yang digunakan pada penelitian ini bertujuan untuk mengetahui pandangan masing-masing responden mengenai variabel standar kontrak FIDIC conditions of contract for EPC/turnkey (silver Book) serta standar kontrak EPC/turnkey dari pengguna jasa.

Uji RII dilakukan kepada responden dari berbagai background pengetahuan yang berkaitan langsung dengan kegiatan pekerjaan pembangunan pembangkit listrik, dimana hasil analisis RII tersebut ditampilkan pada tabel di bawah ini. 
Tabel 2. RII Dari sisi Pengguna Jasa untuk Faktor Penyebab Klaim Proyek Fast Track Program I (FTP I)

\begin{tabular}{|c|c|c|c|c|c|}
\hline \multicolumn{2}{|r|}{$\begin{array}{l}\text { Penyebab Klaim } \\
\text { Konstruksi }\end{array}$} & \multirow{2}{*}{$\begin{array}{c}\mathbf{N} \\
36\end{array}$} & \multirow{2}{*}{$\begin{array}{c}\mathbf{W} \\
159\end{array}$} & \multirow{2}{*}{$\begin{array}{c}\text { RII } \\
0.883\end{array}$} & \multirow{2}{*}{$\begin{array}{c}\text { RANK } \\
1\end{array}$} \\
\hline D6 & Variation order & & & & \\
\hline $\mathrm{C} 2$ & Defective works & 36 & 158 & 0.878 & 2 \\
\hline A6 & $\begin{array}{l}\text { Changes in scope of } \\
\text { work }\end{array}$ & 36 & 154 & 0.856 & 3 \\
\hline B5 & $\begin{array}{l}\text { Unforseeable } \\
\text { physical conditions }\end{array}$ & 36 & 154 & 0.856 & 4 \\
\hline A23 & Variation in quantity & 36 & 153 & 0.850 & 5 \\
\hline E7 & Interest rate & 36 & 152 & 0.844 & 6 \\
\hline A2 & $\begin{array}{l}\text { Availability of } \\
\text { Labour }\end{array}$ & 36 & 151 & 0.839 & 7 \\
\hline $\mathrm{C} 6$ & $\begin{array}{l}\text { Lack of } \\
\text { communication } \\
\text { among parties }\end{array}$ & 36 & 151 & 0.839 & 8 \\
\hline A10 & $\begin{array}{l}\text { Delays caused by the } \\
\text { employer }\end{array}$ & 36 & 150 & 0.833 & 9 \\
\hline A15 & $\begin{array}{l}\text { Late drawing and } \\
\text { instruction's } \\
\text { approvals }\end{array}$ & 36 & g150 & 0.833 & 10 \\
\hline $\mathrm{C} 10$ & $\begin{array}{l}\text { Slow decision } \\
\text { making involving all } \\
\text { parties }\end{array}$ & 36 & 150 & 0.833 & 11 \\
\hline D4 & $\begin{array}{l}\text { Delayed payment on } \\
\text { contract and extras }\end{array}$ & 36 & 150 & 0.833 & 12 \\
\hline A11 & $\begin{array}{l}\text { Delays caused by the } \\
\text { contractor }\end{array}$ & 36 & 149 & 0.828 & 13 \\
\hline D2 & $\begin{array}{l}\text { Constructive change } \\
\text { orders }\end{array}$ & 36 & 149 & 0.828 & 14 \\
\hline A19 & $\begin{array}{l}\text { Possesion of site and } \\
\text { availability }\end{array}$ & 36 & 148 & 0.822 & 15 \\
\hline A22 & $\begin{array}{l}\text { Sub-contracting } \\
\text { problems }\end{array}$ & 36 & 148 & 0.822 & 16 \\
\hline D5 & $\begin{array}{l}\text { Different } \\
\text { interpretation of } \\
\text { contract document }\end{array}$ & 36 & 148 & 0.822 & 17 \\
\hline A7 & $\begin{array}{l}\text { Contractor's late } \\
\text { completion }\end{array}$ & 36 & 147 & 0.817 & 18 \\
\hline A12 & $\begin{array}{l}\text { Design errors and } \\
\text { omissions }\end{array}$ & 36 & 147 & 0.817 & 19 \\
\hline $\mathrm{A} 24$ & Work stoppages & 36 & 147 & 0.817 & 20 \\
\hline $\mathrm{C} 1$ & Accidents / Safety & 36 & 147 & 0.817 & 21 \\
\hline D3 & $\begin{array}{l}\text { Delayed dispute } \\
\text { resolution }\end{array}$ & 36 & 147 & 0.817 & 22 \\
\hline E1 & $\begin{array}{l}\text { Changes in law and } \\
\text { regulations }\end{array}$ & 36 & 147 & 0.817 & 23 \\
\hline B4 & $\begin{array}{l}\text { Subsurface } \\
\text { conditions of ground } \\
\text { water }\end{array}$ & 36 & 145 & 0.806 & 24 \\
\hline E6 & Inflation & 36 & 145 & 0.806 & 25 \\
\hline
\end{tabular}

Dari hasil analisis data kuesioner dengan menggunakan metode RII (Relative Important Index), didapat sepuluh (10) tertinggi penyebab klaim konstruksi, seperti tertera pada tabel 2 di atas.

\section{Analisis Perbandingan In-House Form of General Conditions of Contract terhadap Model Kontrak FIDIC Conditions of Contract for EPC/Turnkey}

Perubahan desain atau spesifikasi (variation order) dan Perubahan lingkup pekerjaan (changes in scope of work) terlihat pada klausul berikut.

a. Klausul di dalam In-House Form of General Conditions of Contract yang terkait dengan faktor penyebab klaim konstruksi akibat perubahan desain dan perubahan lingkup pekerjaan adalah Klausul 2.47 variations

b. Klausul di dalam FIDIC conditions of contract for EPC/turnkey yang terkait dengan faktor penyebab klaim konstruksi akibat perubahan desain dan perubahan lingkup pekerjaan ada pada klausul 13 variation and adjusments, yang dimana diatur lebih lanjut dengan 7 sub-klausul.

c. Pembahasan perbedaan klausul antara In-House Form of General Conditions of Contract dan FIDIC conditions of contract for EPC/turnkey terhadap penyebab klaim konstruksi akibat perubahan desain dan perubahan lingkup kerja adalah sebagai berikut :

1) Klausul kontrak antara In-House Form of General Conditions of Contract dan FIDIC conditions of contract for EPC/turnkey pada dasarnya sama-sama mengakomodir terjadinya perubahan pekerjaan, baik itu menambah, mengurangi, dan merubah pekerjaan yang ada.

2) Pada klausul In-House Form of General Conditions of Contract disebutkan bahwa kontraktor wajib melakukan variasi kecil yang tidak signifikan tanpa mengubah harga 
kontrak. Klausul ini mengandung ketidakjelasan terkait ukuran variasi yang dilakukan dan persoalan biaya yang keluar yang menjadikan kontraktor sebagai penanggung biaya tersebut.

3) Prosedur pelaksanaan variasi ataupun perubahan-perubahan pekerjaan tidak diatur lebih rinci pada In-House Form of General Conditions of Contract, dan pada klausul 2.47 [variasi] tersebut juga membunyikan bahwa prosedur dari variasi agar disetujui setelah penandatanganan kontrak atau dalam contract discuss aggrement. Berbeda dengan FIDIC conditions of contract for EPC/turnkey, dimana prosedur variasi sudah diatur lengkap pada klausul 13 [variation and adjusments].

4) Dengan tidak diaturnya prosedur variasi sejak awal, akan mengakibatkan terjadinya proses negosiasi kembali terkait penetapan prosedur variasi nantinya, yang mana proses ini sudah pasti akan memakan waktu.

5) Dengan variasi atau perubahanperubahan yang berlangsung dan menjadi penyebab klaim konstruksi yang paling dominan, maka sudah seharusnya klausul mengenai variasi atau perubahan pekerjaan dinyatakan secara jelas dan lengkap. Pada FIDIC conditions of contract for EPC/turnkey klausul 13 [variation and adjusments] yang terdiri dari 7 sub-klausul, telah diatur mengenai hak pemilik pekerjaan untuk melakukan variasi, hak kontraktor untuk mengajukan value engineering, prosedur dari variasi hingga pada masalah penyesuaian pembiayaan dan penyesuaian terhadap hukum.

6) Salah satu contoh kasus penyebab klaim dikarenakan variasi dan/atau perubahan lingkup pekerjaan adalah, pada Proyek pembangkit listrik tenaga uap (PLTU) yang terjadi perubahan lokasi jetty yang semula onshore menjadi offshore, yang dimana pelaksanaannya menimbulkan biaya yang harus dikeluarkan dan ditanggung oleh kontraktor, yang kemudian diajukan kepada pemilik pekerjaan sebagai klaim biaya kompensasi dan dapat diterima pemilik pekerjaan. Dari kasus ini dapat dilihat bahwa kedua model kontrak sudah mengakomodir perubahan, hanya saja kelengkapan klausul persyaratan umum dari kedua model kontrak memiliki perbedaan pembahasan, dimana FIDIC lebih detail menjelaskan klausul variasi dan penyesuaiannya daripada In-House Form of General Conditions of Contract.

Kondisi fisik di lapangan yang tidak terduga (unforseeable physical condition) terdapat beberapa klausul berikut.

a. Klausul di dalam In-House Form of General Conditions of Contract yang terkait dengan faktor penyebab klaim konstruksi akibat Kondisi fisik di lapangan yang tidak terduga adalah klausul 2.10 inspeksi lokasi pekerjaan dan klausul 2.11 kecukupan proposal penawaran.

b. Klausul di dalam FIDIC conditions of contract for EPC/turnkey yang terkait dengan faktor penyebab klaim konstruksi akibat kondisi fisik di lapangan yang tidak terduga ada pada klausul 2.5 site data and items of reference, klausul 4.10 use of site 
data dan klausul 4.12 unforeseeable difficulties

c. Pembahasan perbedaan klausul antara In-House Form of General Conditions of Contract dan FIDIC conditions of contract for EPC/turnkey terhadap penyebab klaim konstruksi akibat kondisi fisik di lapangan yang tidak terduga adalah sebagai berikut :

1) Terkait dengan kondisi yang tidak terduga, In-House Form of General Conditions of Contract lebih melimpahkan risiko kepada kontraktor. Pada klausul 2.10 [inspeksi lokasi pekerjaan], pada klausul ini kontraktor diminta lebih aktif dan mandiri untuk memeriksa lokasi, serta dianggap telah memahami risiko yang akan diterima kontraktor lainnya. Selain klausul 2.10, terdapat juga pada klausul 2.11 [kecukupan proposal penawaran] yang setidaknya menyatakan bahwa tidak ada klaim yang akan dipertimbangkan untuk biaya dan perpanjangan waktu. Disisi lain tidak terjelaskan pada klausul manapu terkait kondisi data yang dimiliki oleh pemilik pekerjaan yang dapat digunakan oleh kontraktor. Dari sini terlihat bahwa kontraktor akan menerima risiko kondisi lapangan dengan upaya inspeksi dari dirinya sendiri.

2) Pada klausul FIDIC conditions of contract for EPC/turnkey, kondisi yang tidak terduga ini, baik untuk lokasi pekerjaan dan kondisi dibawah tanah yang diatur bahwa pemilik pekerjaan juga harus menyediakan informasi kepada kontraktor hal ini tertuang pada klausul 2.5 [site data and items of reference]. Yang dimana pada In-
House Form of General Conditions of Contract tidak mengakomodir kesedian data ini pada persyaratan umum nya.

3) Dengan membandingkan klausul inspeksi lapangan In-House Form of General Conditions of Contract dengan model kontrak FIDIC conditions of contract for EPC/turnkey klausul $\quad 4.12$ [unforeseeable condition] yang diketahui bahwa kedua model kontrak mengalihkan risiko kepada kontraktor dan setelah tanda tangan perjanjian maka kontraktor menerima total tanggung jawab karena telah memprediksi semua kesulitan.

4) Dari 3 poin di atas maka model kontrak FIDIC conditions of contract for EPC/turnkey lebih mengakomodir keseimbangan pembagian risiko, dimana pemilik pekerjaan juga menyediakan informasi namun tidak bertanggung jawab terhadap keakuratan, kecukupan dan kelengkapan data kecuali dinyatakan pada klausul 5.1.

5) Sebagai salah satu contoh studi kasus adalah, pada salah satu pekerjaan pembangkit listrik tenaga uap (PLTU), telah dilakukan kajian teknik oleh konsultan independen dengan kesimpulan bahwa data-data tanah yang disampaikan pada saat proses lelang adalah mirip akan tetapi data yang disajikan kurang lengkap sehingga tidak menjelaskan karakteristik tanah yang sesungguhnya. Hal ini menyebabkan adanya beban biaya yang harus ditanggung oleh kontraktor untuk menyelesaikan pekerjaan pondasi circulating water pump house. 
Kondisi tersebut di luar kewenangan kontraktor yang tidak dapat diprediksi sebelumnya sehingga kontraktor dapat mengajukan klaim unforeseen soil condition in CWPH. dan klaim ini dapat diakomodir dengan klausul 2.43 [extension of time for completion] dengan contract discussion agreement, dimana kontraktor memiliki risiko apa yang menjadi tanggung jawabnya sehingga kontraktor tidak boleh dirugikan dengan menanggung risiko di luar yang telah ditentukan dalam kontrak EPC. Namun terkait hal unforeseen condition ini yang juga menyebabkan klaim extension of time akibat dari keterlambatan atau penundaan akibat unforeseen condition in CWPH tersebut, kontraktor dapat mendapatkan perpanjangan waktu penyelesaian pekerjaan, walaupun keterlambatan dan penundaan tidak diatur secara lengkap pada klausul 2.43, namun secara umum klausul tersebut telah mengatur kondisi yang demikian.

Hasil pekerjaan yang cacat atau tidak sesuai (defective works) didapat klausul sebagai berikut.

a. Klausul di dalam In-House Form of General Conditions of Contract yang terkait dengan faktor penyebab klaim konstruksi akibat pekerjaan yang cacat ada pada klausul 2.38 penolakan dan klausul 2.59 cacat setelah pengambil alihan.

b. Klausul di dalam FIDIC conditions of contract for EPC/turnkey yang terkait dengan faktor penyebab klaim konstruksi akibat pekerjaan yang cacat ada pada klausul 7.5 defects and rejection, klausul 7.6 remedial work, klausul 11.1 completion of outstanding work and remedying defects, klausul 11.2 cost of remedying defect, klausul 11.3 extension of defects notification periode, klausul 11.4 failure to remedy defects, klausul 11.5 remedying of defective work off site, klausul 11.6 further test after remedying defects, klausul 11.7 right of access after taking over, klausul 11.8 contractor to search, dan klausul 11.10 unfulfilled obligations.

d. Pembahasan perbedaan klausul antara In-House Form of General Conditions of Contract dan FIDIC conditions of contract for EPC/turnkey terhadap penyebab klaim konstruksi akibat pekerjaan yang cacat atau tidak sesuai adalah sebagai berikut :

1) Klausul penolakan di dalam In-House Form of General Conditions of Contract ada pada klausul 2.38 [penolakan], klausul ini menyatakan bahwa selagi pekerjaan belum diambil alih, maka pemilik pekerjaan dapat memutuskan bahwa pekerjaan atau sebagian pekerjaan adalah cacat atau tidak sesuai kontrak. Dan akan melakukan pemberitahuan kepada kontraktor. Klausul ini menyatakan hal yang sama dengan klausul 7.5 [defect and rejection] FIDIC conditions of contract for EPC/turnkey.

2) Salah satu perbedaan yang dari kedua model kontrak tersebut adalah tidak adanya batasan waktu terkait pemberitahuan yang harus diberikan oleh pemilik pekerjaan kepada kontraktor terkait proposal perbaikan yang diajukan kontraktor. Sedangkan pada klausul model kontrak FIDIC conditions of contract for EPC/turnkey, ditetapkan pemilik pekerjaan harus memberikan 
pemberitahuan kepada kontraktor dalam 14 hari, apabila hal tersebut tidak dilakukan maka pemilik pekerjaan telah memberikan pemberitahuan tidak ada keberatan.

3) Perbedaan lainnya adalah terkait penanganan perbaikan pekerjaan, apabila di In-House Form of General Conditions of Contract menyampaikan secara umum bahwa pemilik pekerjaan dapat melakukan perbaikan kerusakan dengan risiko dan biaya dari kontraktor, namun tidak diatur secara jelas dan lengkap mengenai proses-proses perbaikan yang dilakukan oleh pemilik pekerjaan. Sedangkan pada klausul 7.6 [remedial work] FIDIC conditions of contract for EPC/turnkey, pekerjaan perbaikan diatur secara detail terkait instruksi pemilik pekerjaan kepada kontraktor. Dan juga diatur mengenai pekerjaan perbaikan yang tidak ditanggung oleh kontraktor yang dimana pada In-House Form of General Conditions of Contract, hal tersebut tidak diatur.

4) Setelah klausul mengenai penolakan, maka disusul dengan klausul terkait kecacatan setelah pengambil alihan. Pada In-House Form of General Conditions of Contract hal ini diatur pada klausul 2.59 [cacat setelah pengambilalihan], yang pada intinya kontraktor harus bertanggungjawab memperbaiki dengan risiko dan biaya sendiri. Pemilik pekerjaan akan menyampaikan pemberitahuan kepada kontraktor secara tertulis dan kontraktor akan secepatnya mengganti atau memperbaiki pekerjaan yang tidak sesuai. Terkait dengan garansi dari kecacatan tersebut selanjutnya diatur oleh klausul 2.34 [garansi]. Kontraktor juga memiliki waktu 15 hari utntuk melakukan pekerjaan perbaikan. Dan apabila kontraktor tidak dapat melaksanakan perbaikan dalam jangka waktu 3 bulan setelah pemberitahuan dari pemilik pekerjaan, maka pemilik pekerjaan dapat mengklaim jaminan bank yang adil dalam posisi tersebut. Dan kembali klausul ini mengatur secara umum terkait proses inspeksi, penyesuaian, penggantian dan pembaruan dan untuk semua pengujian sesuai dengan klausul tersebut.

5) Sedangkan pada model kontrak FIDIC conditions of contract for EPC/turnkey, kecacatan setelah pengambil alihan diatur pada klausul 11 [defect after taking over] dengan 11 sub-klausul, dimana setiap subklausul mengatur lebih rinci terkait kecacatan yang setelah pengambilalihan. Pada klausul 11.2 [cost of remedying defect] yang salah satu bunyinya adalah kecacatan yang disepakati disebakan oleh sebab yang lain maka sub-klausul 13.3.1 [variation by instruction]. Selain itu sub-klausul FIDIC conditions of contract for EPC/turnkey ini juga mengatur perpanjangan periode pemberitahuan kecacatan pada klausul 11.3, dimana pada model InHouse Form of General Conditions of Contract, hal ini tidak diatur sama sekali.

6) Perbandingan mengenai klausul kecacatan setelah pengambil alihan ini, sangat lengkap diatur pada model kontrak FIDIC conditions of contract for EPC/turnkey, walaupun pada InHouse Form of General Conditions of 
Contract juga diatur, namun terlalu umum dan kurang mendetail.

\section{Kesimpulan}

1. Berdasarkan rangking RII variabel penyebab klaim konstruksi hasil analisis dan pengolahan data yang dilakukan diperoleh bahwa semua variabel penyebab klaim konstruksi termasuk dalam kategori sangat setuju karena mempunyai nilai $\mathrm{RII} \geq 0,813$, maka 25 penyebab klaim konstruksi tersebut sangat berpotensi muncul di konstruksi pembangkit.

2. In-House Form of General Conditions of Contract dan model kontrak FIDIC conditions of contract For EPC/turnkey (silver book) memiliki gap yang dapat dilihat dari kelengkapan klausul dalam menjelaskan pernyataan didalamnya, sebagai contoh pada klausul variasi dan penyesuaian dimana pada model kontrak FIDIC diatur menjadi lebih dari 7 subklausul sementara pada In-House Form of General Conditions of Contract hanya terdapat 1 klausul tanpa sub-klausul.

3. Standar kontrak FIDIC conditions of contract For EPC/turnkey (silver book) lebih tepat untuk menjadi model kontrak konstruksi pembangkit daripada standar kontrak internal pengguna jasa.

\section{Daftar Pustaka}

Hardjomuljadi, Sarwono (2011), The Main Causal Factors of Construction Claims Under FIDIC Contract in Indonesia, Universitas Mercu Buana, Jakarta

Hardjomuljadi, Sarwono (2014), Analisis "Extension of Time" dan Dampaknya pada Kontrak Konstruksi (FIDIC Conditions of Contract MDB Harmonised Edition), Jurnal Konstruksia, vol. 5 no. 2
Hardjomuljadi, Sarwono (2014), Analysis on The Possession of Site as Physical Cause of Claim and the Related Clauses in the "FIDIC Conditions of Contract for Construction MDB Harmonised Edition", Journal of Basic and Applied Scientific Research, vol. 12 no. 5

Hardjomuljadi, Sarwono (2014), Factor Analysis on Causal of Construction Claims and Disputes in Indonesia (with Reference to the Construction of Hydroelectric Power Project in Indonesia), International Journal of Applied Engineering Research, vol. 9 no. 22

Hardjomuljadi, Sarwono (2016), Variation Order, The Causal or the Resolver of Claims and Disputes in the Construction Projects, International Journal of Applied Engineering Research, vol. 11 no. 14 page $8128-8135$

Hardjomuljadi, Sarwono (2017), Analisis Pemilihan Model Kontrak FIDIC Rainbow Contract 2017 Pekerjaan Pembangunan Dermaga (Kajian Dari Sudut Pandang Pengguna Jasa), Jurnal Konstruksia, vol. 9 no.2

Hardjomuljadi, Sarwono (2014), Factor Analysis on Causal of Construction Claim and Disputes in Indonesia (with Reference to the Construction of Hydroelectric Power Project in Indonesia), International Journal of Applied Engineering Research, vol. 9 no. 22

Hardjomuljadi, Sarwono (2015), EPC/Turnkey Contract, Lumpum Fixed Price Subject to Adjusments, Jurnal Konstruksia

Hardjomuljadi, Sarwono; Abdulkadir, Ariono and Takei, Masaru (2006), Construction Claim Strategy based on FIDIC Conditions of Contract, ISBN : 97997749-2-6, Polagrade, Jakarta 
Hardjomuljadi, Sarwono (2014), Buku Kesatu Pengantar Kontrak Konstruksi FIDIC Conditions of Contract, ISBN : 978-602-9272-13-0, Logoz Publishing, Bandung

Hardjomuljadi, Sarwono (2015), Buku Kedua Manajemen Klaim Konstruksi FIDIC Conditions of Contract, ISBN : 978-602-9272-37-6, Logoz Publishing, Bandung

Hardjomuljadi, Sarwono (2016), Buku Ketiga Alternatif Penyelesaian Sengketa Konstruksi Di Indonesia, ISBN : 978602-9272-39-0, Logoz Publishing, Bandung

Soeharto, Iman (2001), Manajemen Proyek (Dari Konseptual Sampai Operasional, Jilid 2, Erlangga

Martanti, Ana Yuni and Hardjomuljadi, Sarwono (2018), The Effect of Contract Change Order on Contractor Financing in Government Projects, International Journal of Civil Engineering and Technology (IJCIET), vol. 9, Issue 6 page 665-671

Nurmala, Ade and Hardjomuljadi, Sarwono (2015), Penyebab dan Dampak Variation Order (VO) pada Pelaksanaan Proyek Konstruksi, Jurnal Konstruksia, vol. 6 no. 2

Sudirman, Weddy B. and Simanjuntak, Manlian Ronald A. (2018), Risk Factor Indentification for EPC Contract of Power Plant Projects using In-House From of General Conditions of Contract in Indonesia, Journal of Scientific and Engineering Research, vol. 5(4) page 309-319

Taurano, G Adya dan Hardjomuljadi, Sarwono (2013), Analisis Faktor Penyebab Klaim Pada Proyek Konstruksi Yang Menggunakan FIDIC Conditions of Contract for Plant and Design Build, Jurnal Konstruksia vol. 5 no. 1 
